\title{
NUMERICAL INVESTIGATION OF ROUGNESS EFFECTS ON HYDERDYNMIC AND THERMAL PERFORMANCE OF COUNTER FLOW MICROCHANNEL HEAT EXCHANGER
}

\author{
Ahmed A. Ali \\ Mechanical Engineering Department, College of Engineering, Thi-Qar University, Iraq \\ E mail: eng.ahmedameen91@gmail.com
}

Mushtaq I. Hasan

Mechanical Engineering Department, College of Engineering, Thi-Qar University, Iraq E mail: mushtaq76h@gmail.com

Ghassan Adnan

Mechanical Engineering Department, College of Engineering, Thi-Qar University, Iraq E mail: Ghassanadnan37@gmail.com

\begin{abstract}
In this paper the effect of surface roughness on the performance of counter flow microchannel heat exchanger has been numerically investigated. The studied Microchannel heat exchanger is a square shape and made of aluminum as substrate material with different values of hydraulic diameters $(20,50,110,150) \mu \mathrm{m}$. The working fluid used is water at constant properties. Roughness- viscosity model has been used to study the roughness effect with 0.14 ratio of roughness to hydraulic diameter. The results obtained indicate that pressure drop of (CFMCHX) increased with increasing surface roughness and decrease hydraulic diameter also the results showed that there is a slight increasing in thermal performance with increasing the surface roughness.
\end{abstract}

Keywords: surface roughness, Microchannel heat exchanger, Laminar flow, Numerical investigation, Thermal performance 


\section{NOMENCLATURE:}

\begin{tabular}{|c|c|c|}
\hline Symbol & Description & SI unit \\
\hline $\mathrm{C}_{\mathrm{p}}$ & specific heat & Jlkg.K \\
\hline$D_{h}$ & hydraulic diameter & $\mathrm{m}$ \\
\hline $\mathrm{F}$ & friction factor & \\
\hline $\mathrm{H}$ & height & $\mathrm{m}$ \\
\hline K & height of the roughness element & $\mathrm{m}$ \\
\hline$m$ & Mass flow rate & $\mathrm{kg} / \mathrm{s}$ \\
\hline P.P & Pumping poewer & Watt \\
\hline $\mathrm{T}$ & Temperture & k \\
\hline$U_{k}$ & velocity at the top of roughness & $\mathrm{m} / \mathrm{s}$ \\
\hline Uavg & average velocity & $\mathrm{m} / \mathrm{s}$ \\
\hline$U$ & fluid $x$-component velocity & $\mathrm{m} / \mathrm{sec}$ \\
\hline $\operatorname{Re}$ & Reynold number & \\
\hline $\mathrm{Re}_{\mathrm{k}}$ & local Reynold number & \\
\hline RVM & roughness viscosity model & \\
\hline W & width & $\mathrm{m}$ \\
\hline$\Delta \mathrm{P}$ & $\begin{array}{l}\text { pressure drop across heat } \\
\text { exchanger }\end{array}$ & pa \\
\hline$P$ & density & $\mathrm{kg} / \mathrm{m}^{3}$ \\
\hline$\mu_{\mathrm{R}}$ & roughness viscosity & $\mathrm{m}^{2} / \mathrm{s}$ \\
\hline Mp & apparent viscosity & $\mathrm{m}^{2} / \mathrm{s}$ \\
\hline$\eta^{*}$ & Performance factor & \\
\hline$\varepsilon$ & Heat exchanger effectiveness & \\
\hline
\end{tabular}




\section{INTRODUCTION}

In recent years, advanced micro fabricated technology as heat exchanger received large interest and increase the using in many applications due to heat transfer dissipation over small size this invites to use it in biomedical process, microelectronics ,metrology and aerospace application so the study of the overall performance of microchannel heat exchanger with different parameters is very important[1]. Decreasing the hydraulic diameter has a considerable effect on all parameters also the roughness effect play important role on hydraulic and thermal performance of microchannel heat exchanger (MCHX). There are many researches in literature studied many parameters affecting the performance of microchannel heat exchanger including roughness effect. Below a review of most related papers.

Mala and Li (1999) [2] presented experimental work to investigate the performance on microchannel with diameter ranging from $(50$ - 254) $\mu \mathrm{m}$ by using roughness - viscosity model. [RVM] has been used to study the roughness effect on microchannel. [RVM ] treat the roughness effect as apparent viscosity in momentum equation. The apparent viscosity $\mu_{p}$ is the sum of viscosity of fluid $\mu_{f}$ and roughness viscosity $\mu_{R}$. The authors solved the momentum equation analytically for cylinder with adding the roughness viscosity. [RVM] appears large agreement with experimental data in varying hydraulic diameter. Their results showed that, the early transition from laminar to turbulent which cause it the effect of surface roughness. Weilin et al (2000)[3] studied experimentally micro aching techniques fabricated the trapezoidal channel with relative roughness value $(2.4 \%-3.5 \%)$ due to silicon surface finish and hydraulic diameter ranging ( 51-169 ) $\mu \mathrm{m}$ .they concluded that the friction factor and pressure drop in microchannel higher than those given by conventional theory due to the surface roughness effect. Qu et al (2000) [4] Studied the effect of surface roughness on heat transfer characteristics of water as working fluid flow through trapezoidal silicon microchannel with the hydraulic diameter ranging from ( 62-169) $\mu \mathrm{m}$. They found that, the velocity near the wall surface is decreased due to the effect of surface roughness. They proposed a roughness - viscosity model [RVM] to interpret their experimental data based on this model. Hassan. et al (2009) [5] evaluated the effect of channel geometry fluid flow and heat transfer behavers of counter flow microchannel heat exchanger by using numerical simulation. The effects of different channel shapes on performances of (CFMCHX) are studied for five shapes (square, rectangular, triangular, trapezoidal and circle). The results showed that, for the same volume of heat exchanger, increase number of channel leads to increase both pressure drop and effectiveness also they developed a new correlations to predicted the value of heat exchanger effectiveness and performance index as function of relative size channel with Re, overall volume of heat exchanger and thermal conductivity ratio.Dang.et al (2010) [6]presented experimental testes and numerical simulation to study the fluid flow and heat transfer characteristics of counter microchannel heat exchanger for rectangular shaped has hydraulic diameter of $375 \mu \mathrm{m}$ and heat flux applied was $17.38 \mathrm{w} / \mathrm{cm}^{2}$ was achieved for water from cold side having inlet temperature of $21.5^{\circ} \mathrm{C}$ and mass flow rate $0.2906 \mathrm{~g} / \mathrm{sec}$ and for hot side having inlet temperature $70{ }^{\circ} \mathrm{C}$ and mass flow rate $0.2503 \mathrm{~g} / \mathrm{sec}$. from result obtained that, 


\section{AL-QADISIYAH JOURNAL FOR ENGINEERING SCIENCES}

Vol. 11 , No. 4

ISSN: $1998-4456$

pressure drop increase as water temperature rises where pressure drop increases from 880 to $4400 \mathrm{pa}$. also obtained a good agreement between numerical and experimental results. Byongjoo kim (2016) [7] Investigated microchannel to study the flow resistance and thermal behavior in ten rectangular microchannel with aspect ratio ranging from $(0.25-3.8)$. He used FC 770 and deionized water as working fluids. The relative roughness measured by digital device was $3.7 \mathrm{~mm}$. He observed through experimental demonstrate large deviation in poiseuille number(fRe) because the surface roughness as the channel size decrease. Also the result showed that ,the existing roughness in microchannel cause early transition to turbulent flow.

In this paper the effect of the surface roughness on the performance of counter flow microchannel heat exchanger will be numerically studied by using roughness - viscosity model on thermo- hydraulic characteristics .In addition to relation between channel and roughness effect.

\section{MATHMATICAL MODEL:}

The schematic drawing in fig (1) shows a physical model of problem. Which represents counter flow microchannel heat exchanger (CFMCHX) consists of square channels with hot and cold fluids where the working fluid ( water) inters in upper channel as cold fluid while in the lower as hot fluid. There are many diffcults with soling complet heat excanger, where need much time and super computers there fore one unit is used in this study. The selected unit consists of hot and cold channel and separating wall between them. For each channel the length (L) equal to $500 \mu \mathrm{m}$, width of the channel( $W$ ), (ts) is the thickness of separating wall between cold and hot fluid of $(5 \mu \mathrm{m})$ and the aspect ratio equals to one as seen in fig. 2

The governing equations used in this paper based on the following physical and geometry assumptions :

- The flow is laminar and steady.

- The value of Knudsen number is smaller thane 0.001 for continuance fluid (no slip).

- Water used in this paper is incompressible, constant properties and Newtonian.

- There is no heat transfer tolfrom the ambient

- The energy dissipation is negligible.

- The pressure drop in axial direction only.

- Three dimensional flow and heat transfer .

The governing equations and boundary conditions in Cartesian are write below [8] [9][10] Continuity equation: 
$\nabla V=0$

Momentum equation:

$\rho(V . \nabla V)=-\nabla P+\nabla \cdot(\mu \nabla V)$

Energy equation:

$\rho C_{p}(V \nabla T)=k \nabla^{2} T$

Mala and Li [2] modified roughness viscosity model where surface roughness in laminar flow considered in terms roughness - viscosity function . the apparent viscosity in momentum equations become viscosity of fluid sum roughness viscosity as equ.9. the ratio of roughness to hydraulic diameter is 0.14 and $k$ is average height of surface roughness.

$$
\left.\frac{\mu R}{\mu}=(4)\right) A \operatorname{Re} e_{k} \frac{r}{k}\left(1-\exp \left(-\frac{R \varepsilon_{k}}{\mathbb{R} \varepsilon} \frac{r}{k}\right)\right)^{2}
$$

$U_{k}=\left(\frac{\partial u}{\partial r}\right) r=k k$

$\operatorname{Re}_{k}=\left(\frac{\partial u}{\partial r}\right)_{r=R} k^{2} / v$

$$
\left(\frac{\partial u}{\partial r}\right)_{\mathrm{r}=\mathrm{R}}=\frac{\pi \varepsilon_{k}}{k^{2}}
$$

$\mathrm{A}=0.1306\left(\frac{R}{k}\right)^{0.3693} \exp \left\{\operatorname{Re}\left(6 \times 10^{-5} \frac{R}{k}-0.0029\right)\right.$

The apparent viscosity of fluid is $\quad \mu p=\mu+\mu R$ 


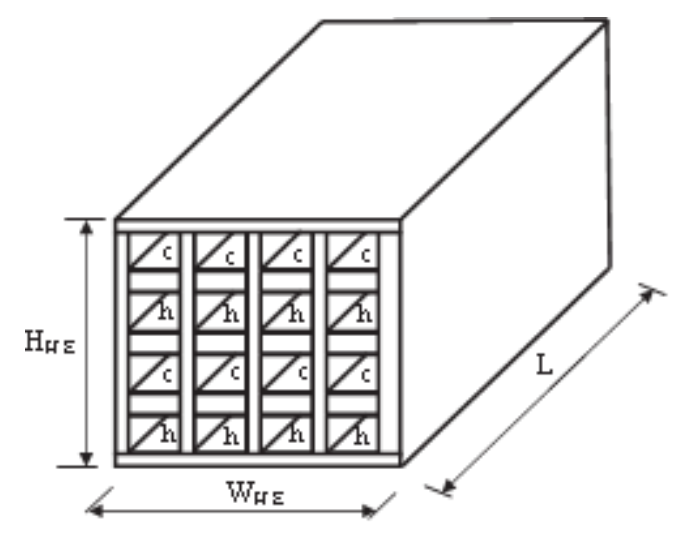

Fig.1.Model of CFMCHX[10]
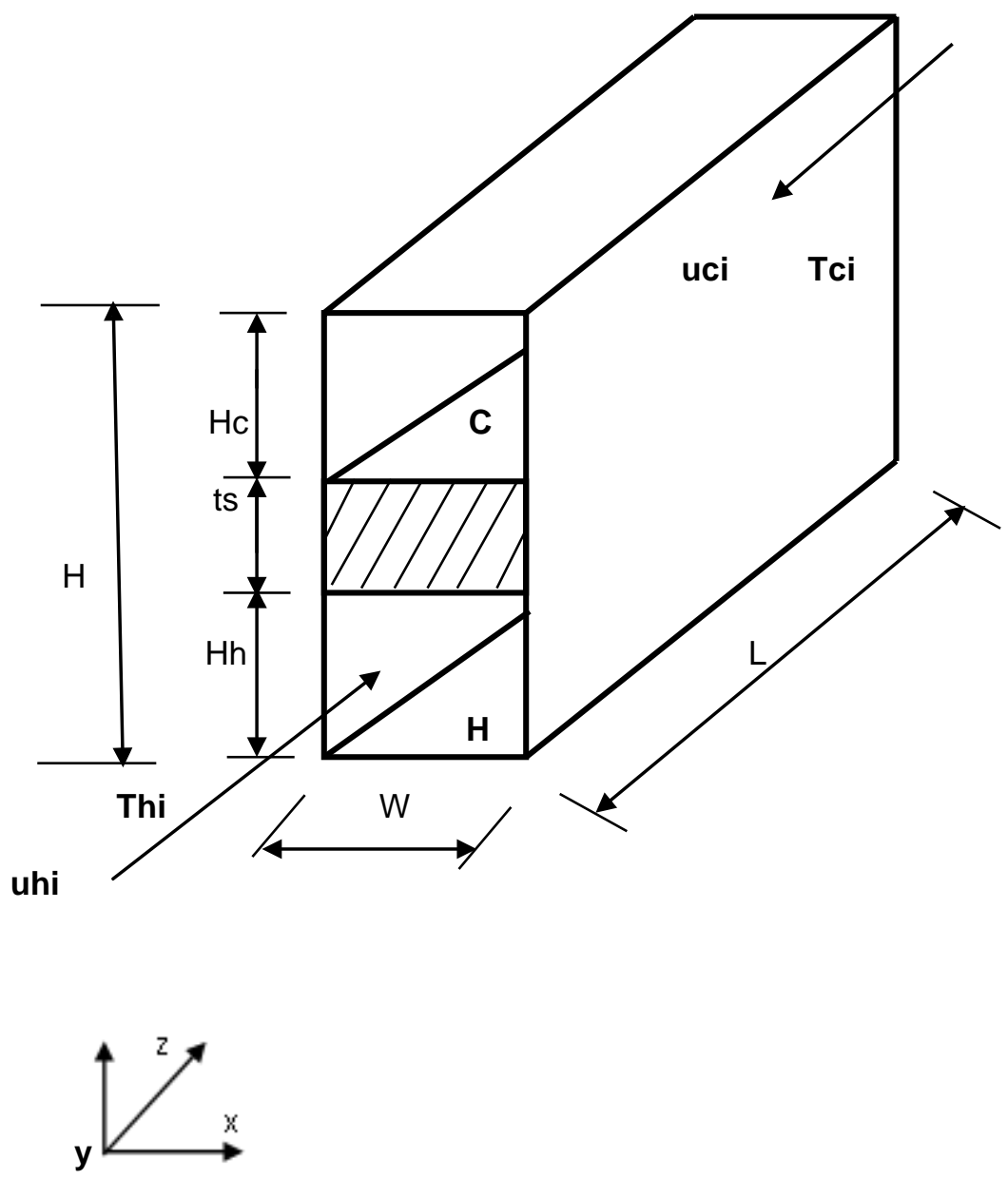

Fig (2) unit cell of CFMCHX[10] 


\section{BOUNDERY CONDITIONS:}

The boundary conditions used to complete the model are:

For lower channel (hot fluid)

\begin{tabular}{|c|c|c|c|}
\hline Location & B.C & & comments \\
\hline At $z=0$ & $\mathrm{u}=\mathrm{u}_{\mathrm{hi}}, \mathrm{v}_{\mathrm{h}}=\mathrm{w}_{\mathrm{h}}=0$ &,$T_{h}=T_{h i}$ & hot fluid in flow \\
\hline At $z=L$ & $\frac{\partial u_{h}}{\partial z}=V h=W_{h}=0$ & $\frac{\partial T}{\partial z}=0$ & hot fluid out flow \\
\hline & & & (fully developed flow, \\
\hline & & & End of channel ) \\
\hline At $x=0$ & $u_{h}=v_{h}=W_{h}=0$ &,$\frac{\partial T_{h}}{\partial x}$ & no- slip, adiabatic wall \\
\hline At $x=w$ & $U_{h}=V_{h}=W_{h}=0$ & $\frac{\partial T_{h}}{\partial x}$ & no- slip, adiabatic wall \\
\hline At $y=0$ & $U_{h}=V_{h}=W_{h}=0$ & $\frac{\partial T_{h}}{\partial y}$ & no- slip, adiabatic wall \\
\hline At $\mathrm{y}=\mathrm{H}_{\mathrm{h}}$ & $\mathrm{U}_{\mathrm{h}}=\mathrm{V}_{\mathrm{h}}=\mathrm{Wh}_{\mathrm{h}}=0$ &,$-\mathrm{k}_{\mathrm{h}} \frac{\partial T_{h}}{\partial y}=-\mathrm{k}_{\mathrm{s}} \frac{\partial T_{y}}{\partial y}$ & fluid - solid interface \\
\hline & & $\mathrm{T}_{\mathrm{s}}=\mathrm{T}_{\mathrm{h}}$ & (no -slip conjgat heat transfer) \\
\hline
\end{tabular}

For upper channel ( cold fluid)

$\left(H_{h}+t \leq y \leq H_{h}+t+H c\right)$

\begin{tabular}{lll}
\hline Location & B.c & comments \\
\hline
\end{tabular}

At $\mathrm{X}=0 \quad \frac{\partial \mathrm{w}_{c}}{\partial x}=\mathrm{V}_{\mathrm{c}}=\mathrm{W}_{\mathrm{c}}=0 \quad \frac{\partial T_{c}}{\partial x}=0 \quad$ cold fluid outlet (fully developed

Fully developed flow end of channel

At $\mathrm{x}=\mathrm{w} \quad \mathrm{u}_{\mathrm{c}}=\mathrm{u}_{\mathrm{ci}}, \mathrm{v}_{\mathrm{c}}=\mathrm{W}_{\mathrm{c}}=0 \quad, \mathrm{Tc}=\mathrm{T}_{\mathrm{ci}} \quad$ cold fluid inflow

At $z=0 \quad \frac{\partial T_{c}}{\partial z}=0 \quad$ No - slip adiabatic wall 


\section{AL-QADISIYAH JOURNAL FOR ENGINEERING SCIENCES}

Vol. 11 , No. 4

ISSN: $1998-4456$

$\begin{array}{lcccc}\text { At } \mathrm{z}=\mathrm{L} & \mathrm{u}_{\mathrm{c}}=\mathrm{v}_{\mathrm{c}=\mathrm{W}_{\mathrm{c}}=0} & , \frac{\partial T_{c}}{\partial z}=0 \quad \text { No }- \text { slip adiabatic wall } \\ \text { At } \mathrm{y}=\mathrm{H}_{\mathrm{h}+\mathrm{t}} & \mathrm{u}_{\mathrm{c}}=\mathrm{v}_{\mathrm{c}=\mathrm{W}_{\mathrm{c}}=0},-\mathrm{k}_{\mathrm{c}} \frac{\partial T_{c}}{\partial y}=-\mathrm{k}_{\mathrm{s}} \frac{\partial T_{x}}{\partial y}, \mathrm{~T}_{\mathrm{c}}=\mathrm{T}_{\mathrm{s}} \quad \text { Fluid -solid interface }\end{array}$

( no slip, conjugate heat transfer)

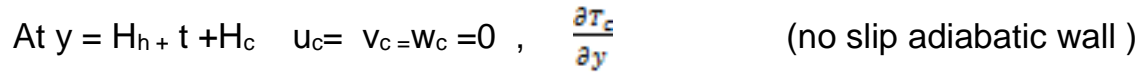

For solid wall separating two channels $\left(H_{h} \leq \mathrm{y} \leq \mathrm{H}_{\mathrm{h}}+\mathrm{t}\right)$

\begin{tabular}{lcc}
\hline Location & B.C & comments \\
\hline At $\mathrm{x}=0$ and $\mathrm{x}=\mathrm{W}$ & $\frac{\partial T_{x}}{\partial x}=0$ & adiabatic wall \\
At $\mathrm{z}=0$ & $\frac{\partial T_{x}}{\partial z}=0$ & adiabatic wall \\
At $\mathrm{z}=\mathrm{L}$ & $\frac{\partial T_{x}}{\partial z}=0$ & adiabatic wall \\
At $\mathrm{y}=\mathrm{Hh}$ & $,-\mathrm{kh}_{\mathrm{h}} \frac{\partial T_{\mathrm{h}}}{\partial y}=-\mathrm{k}_{\mathrm{s}} \frac{\partial T_{x}}{\partial y} \quad, \mathrm{~T}_{\mathrm{s}}=\mathrm{T}_{\mathrm{h}}$ & fluid - solid interface \\
At $\mathrm{y}=\mathrm{H}_{\mathrm{h}+\mathrm{t}}$ & $-\mathrm{k}_{\mathrm{c}} \frac{\partial T_{\mathrm{c}}}{\partial y}=-\mathrm{k}_{\mathrm{s}} \frac{\partial T_{x}}{\partial y} \quad, \mathrm{~T}_{\mathrm{c}}=\mathrm{T}_{\mathrm{s}}$ & Fluid - solid interface
\end{tabular}

By CFD code the above equations with their boundary conditions have been solved, and values of velocity, pressure, effectiveness, pumping power, friction factor and overall performance are calculated

The inlet velocity is calculated based on Reynolds number.

$\mathrm{Re}=\frac{\rho u_{i} D_{h}}{\mu}$

Where $D_{h}$ is the hydraulic diameter.

From Darcy equation can be friction factor [11] 
Vol. 11 , No. 4

ISSN: $1998-4456$

$$
f=\frac{\Delta p}{\boldsymbol{u}_{\text {avg }}^{2}} \frac{2 D}{\rho L}
$$

And the total pressure drop in heat exchanger unit is the summation of the pressure drop in the hot fluid channel and the cold fluid channel.

$\Delta P_{u}=\Delta P_{\text {ch.h }}+\Delta P_{\text {ch.c }}=\left(P_{\text {h.i }}-P_{\text {h.o }}\right)+\left(P_{\text {c.i }}-P_{\text {c.o }}\right)$

Heat exchanger effectiveness is the ratio of the actual heat transfer to the maximum possible heat that can be transferred[10]:

$$
\begin{aligned}
& q=m^{\prime} C_{c}\left(T c_{s_{\text {out }}}-T_{C_{i, \text { in }}}\right)=m^{\prime} C_{h}\left(T h_{\text {sout }}-T_{\text {hin }}\right)
\end{aligned}
$$

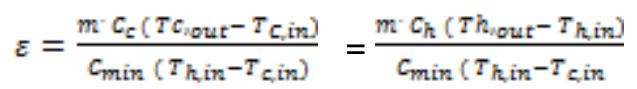

For any heat exchanger the effectiveness is a function of NTU and the heat capacity ratio. $\varepsilon=f$ (NTU, Cr)

Where NTU is the number of transfer units

$$
\mathrm{NTU}=\frac{U_{A}}{C_{M I N}}
$$

And $\mathrm{Cr}$ is the heat capacity ratio

$$
\mathrm{Cr}=\frac{c_{\min }}{c_{\max }}
$$

$\varepsilon=\frac{1-e^{-N T U_{(1-C r)}}}{1-C_{r} e^{-N T U_{(1-C r)}}}$

volumetric flow rate multiplying total drop pressure. [12]

$P . P=\dot{V} \Delta P$

To calculate the performance factor of heat exchanger the performance factor has been used to correlate the hydrodynamic and thermal performance as define below

$$
\eta^{*}=\frac{Q}{P . P}
$$




\section{AL-QADISIYAH JOURNAL FOR ENGINEERING SCIENCES}

Vol. 11 , No. 4

ISSN: $1998-4456$

\section{NUMERICAL SOLUTION:}

The above system of governing equations and boundary conditions are numerically solved using finite volume method. The flow is developing; the 3D continuity and 3D Naiver stock equations are solved numerical by fluent ANSYS. A mesh has been chosen in accepted size and a mesh refinement has been made to find out the appropriate mesh size that gives highly accurate solution as indicate in table (3). Table 3 shows that the solution becomes independent of grid size and from third mesh further increase in the grids will not have a significant effect on the solution and results of such arrangement are acceptable. Therefore the fourth mesh size is used for all calculations.

Table 1 Grid independent study

\begin{tabular}{|c|c|}
\hline Mesh size & Outlet temperature $(\mathrm{K})$ \\
\hline mesh1 (number of elements=1320743) & 308 \\
\hline mesh2 (number of elements=1528356) & 308.93 \\
\hline mesh3 (number of elements=1963380) & 308.95 \\
\hline mesh4 (number of elements=2575633) & 308.96 \\
\hline
\end{tabular}

The convergence criteria used to control the numerical solution for both momentum and energy equations are $10^{-6}$.

The properties of material are list in table (4) below [13 ]

Table (2) properties of selected material

\begin{tabular}{|c|l|l|}
\hline \multirow{2}{*}{ Property } & \multicolumn{2}{|c|}{ Material } \\
\cline { 2 - 3 } & \multicolumn{1}{|c|}{ Water } & \multicolumn{1}{c|}{ Aluminum } \\
\hline Thermal conductivity $(\mathrm{k})\left(\mathrm{W} / \mathrm{m}^{2} . \mathrm{K}\right)$ & 0.643 & 273 \\
\hline Specific heat $\mathrm{Cp}(\mathrm{J} / \mathrm{Kg} . \mathrm{K})$ & 4200 & 871 \\
\hline density $\left(\mathrm{Kg} / \mathrm{m}^{3}\right)$ & 1000 & 2791 \\
\hline Viscosity $\left(\mathrm{m}^{2} / \mathrm{s}\right)$ & 0.001 & - \\
\hline
\end{tabular}




\section{RESULTS}

The model was solved with pure water as a working fluid with constant properties selected according to the mean temperature across heat exchanger. Two cases have been solved for each size with considering surface roughness and with neglecting it to explore the effect of roughness on the performance of (CFMCHX)

To check the validity of the built numerical model, verification was made by solving the experimental model presented in [7] and the results were compared. The experimental model presented in [7] is a rectangular microchannel with aspect ratio $1.92 \mu \mathrm{m}$. The width $(265 \mu \mathrm{m})$, height $(510 \mu \mathrm{m})$, length $(76 \mathrm{~mm})$ and hydraulic diameter $(348.8 \mu \mathrm{m})$. The author used FC770 and deionized water used as working fluid. The surface roughness of aluminum measured was $3.7 \mu \mathrm{m}$ due to surface finish of machining.

Fig. 3 shows the comparison between results of present numerical model and the experimental data of [7] for variation of friction factor with Reynolds number. From this figure it can be seen that, the agreement between numerical and experimental results is acceptable with the average error of $5 \%$ which may be due to difference in material properties and some assumptions in this model.

To check the behaver of thermal side, another validation has been made with reference [14] as shown in fig. 4 shows the validation between results of present model with data in Al- bakhit and Fakeri 2006[14]. The figure explains that, the variation of dimensionless axial distance $\mathrm{x}^{*}=\frac{x}{D h \mathbb{R} p r} \quad$ with dimensionless mean temperature $T_{m}=\frac{T i-T c i}{T_{\text {hin }}-T_{\text {cin }}}$ for the cold and hot fluids flows in rectangular microchannel heat exchanger at Reynold number is 100 and $\frac{k_{y g} D_{h}}{k_{x} t_{s}}=100$. It can be noted in this figure that there is a good agreement between the results of present model and that in [14] where the maximum error was $1 \%$ due to the difference in some assumptions between them. 

AL-QADISIYAH JOURNAL FOR
ENGINEERING SCIENCES
Vol. 11 , No. 4

ISSN: $1998-4456$

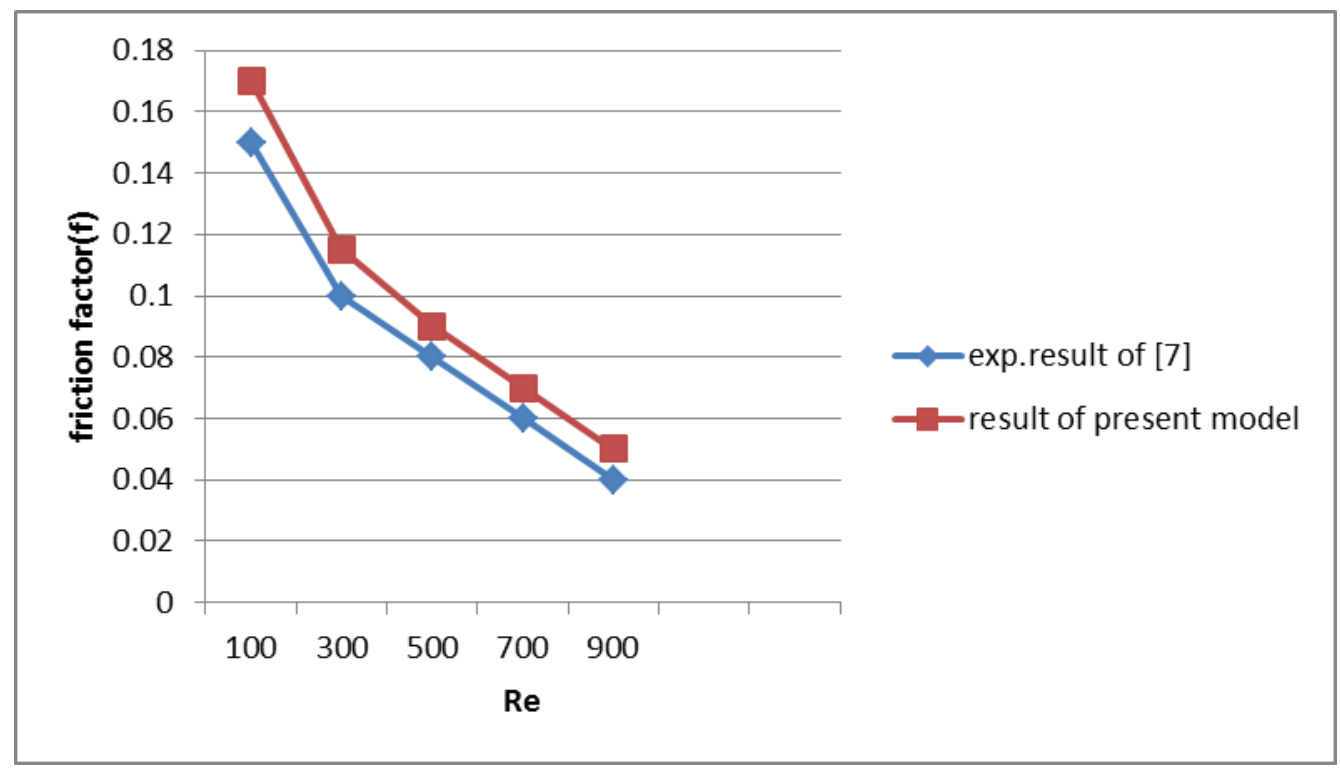

Fig (3) variation of friction factor with Re as comparison between results of present model and that of [7]

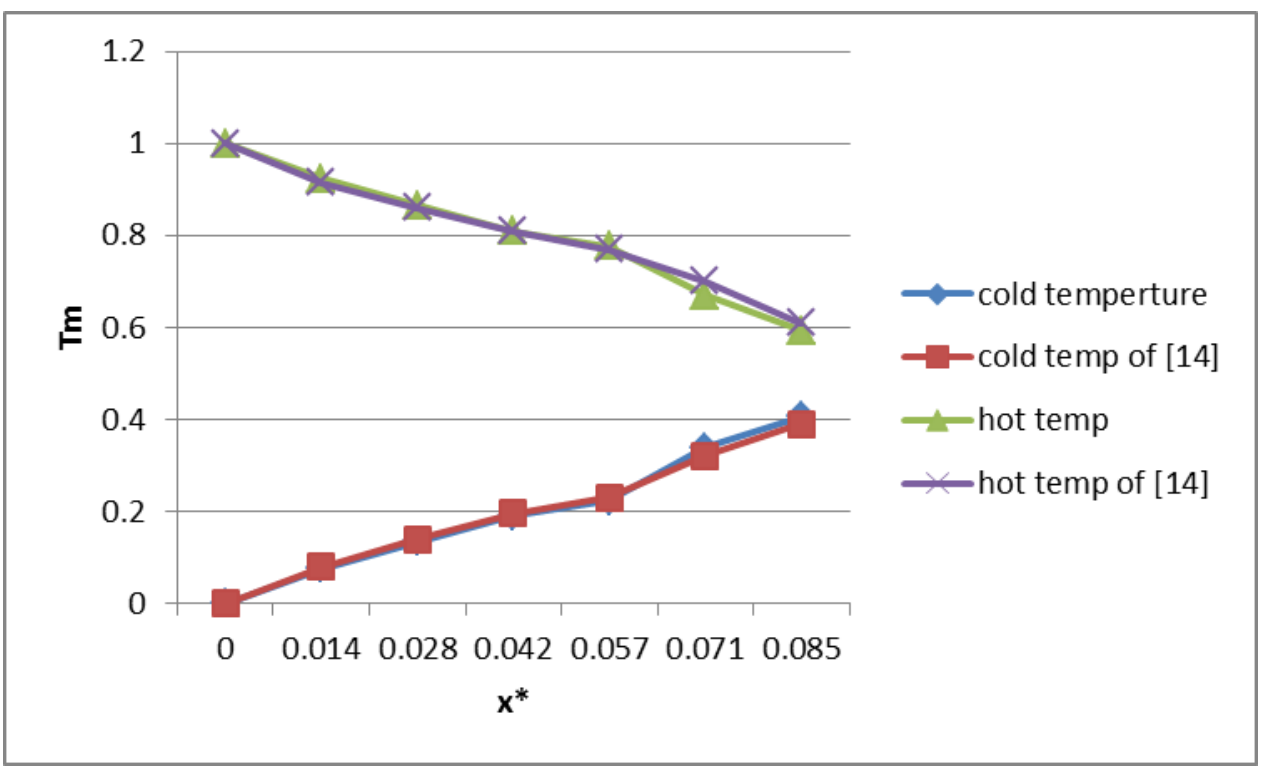

Fig(4) variation of mean temperature with dimensionless distance as comparison between results of present model and that of [14]

Fig (5) shows the velocity variation on planes drawing a long the channels of (CFMCHX). The channels have hydraulic diameter $\left(D_{h}=50 \mu \mathrm{m}\right)$ and $R e=100$. It can observed in this figure that the velocity of flow in entering of cold and hot channels is maximum value and decreasing flow velocity with toward flow. 


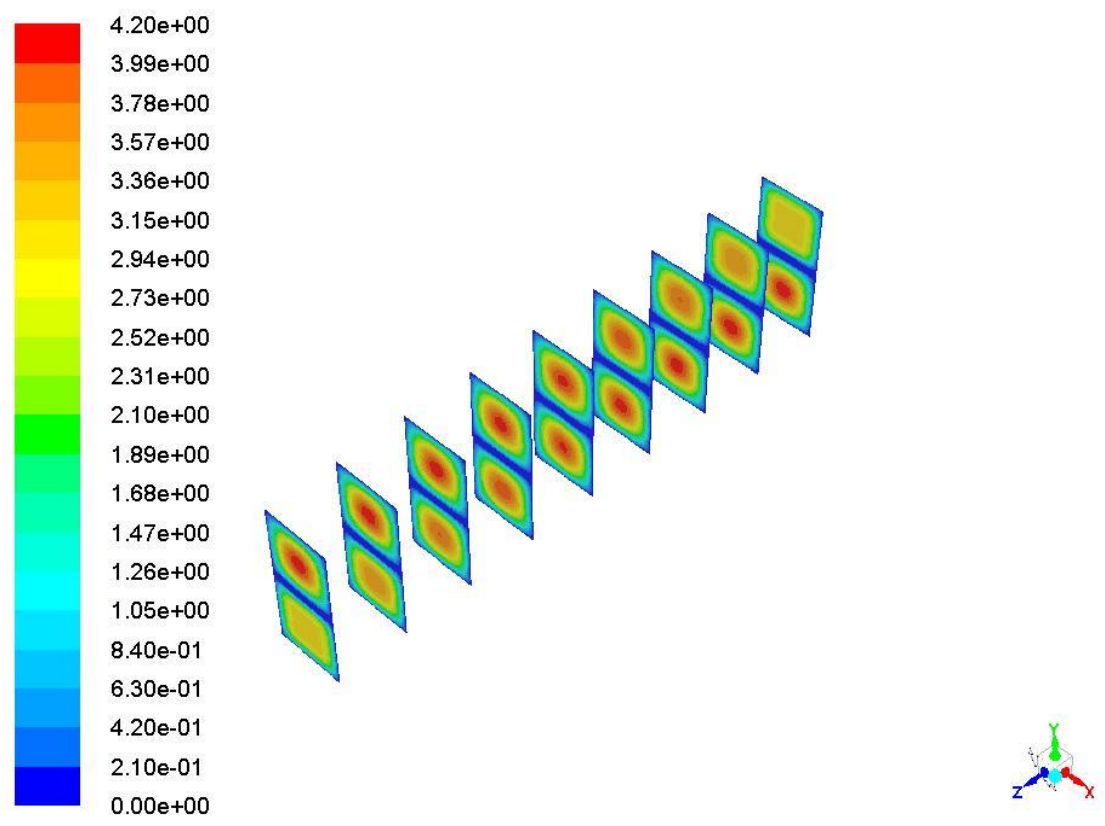

Fig (5) planes of contour represent the velocity $(\mathrm{m} / \mathrm{sec})$ in cold and hot cells of CFMCHX at $D_{h}=50$ $\mu \mathrm{m}$ and $\mathrm{Re}=100$

Fig.6 explains the distribution of pressure drop contour in (y-z) plane at same value of Re and hydraulic diameter of previous figure. Pressure drop in hot channel is larger than cold channel due to affect temperature which leads to increase it. Also it can be seen that the surface roughness increased the pressure drop due the restriction between molecules of fluid.
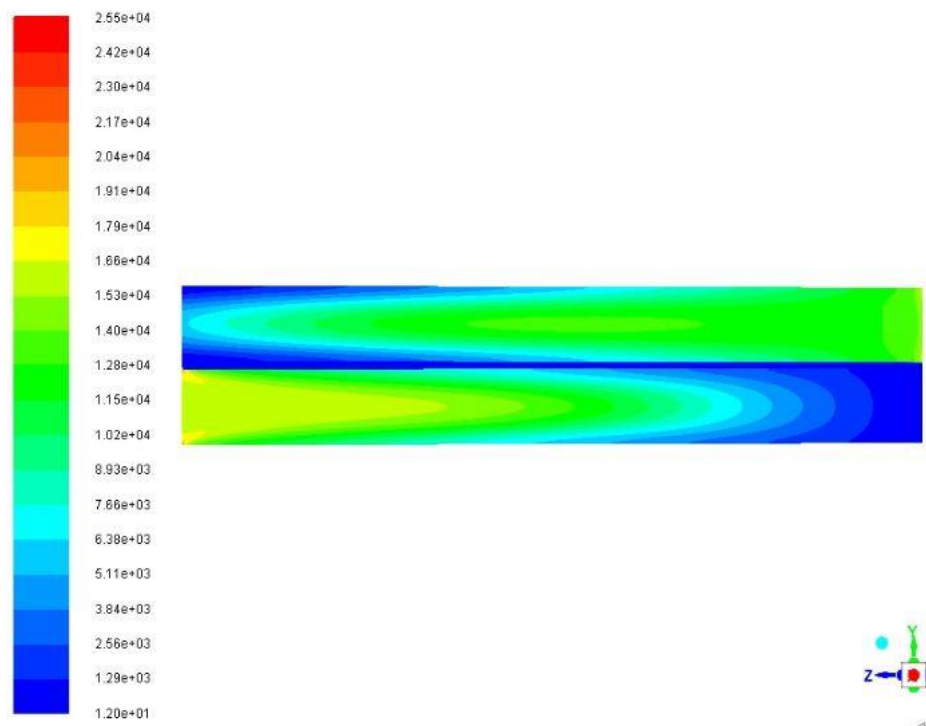

Fig(6) pressure(pa) distribution contour along cold and hot channel of $\mathrm{CFMCHX}$ has $\mathrm{D}_{\mathrm{h}}=50 \mu \mathrm{m}$ and $\quad \operatorname{Re}=100$ 


\section{AL-QADISIYAH JOURNAL FOR ENGINEERING SCIENCES}

Vol. 11 , No. 4

ISSN: $1998-4456$

Fig.7 shows variation of pressure drop at many plane distributions a long hot and cold channel of (CFMCHX) with hydraulic diameter of $\left(D_{h}=50 \mu \mathrm{m}\right)$ and $R e=100$. It can be noted that in fig.7 the pressure drop increased with increasing velocity of flow which due to increase mass flow rate.
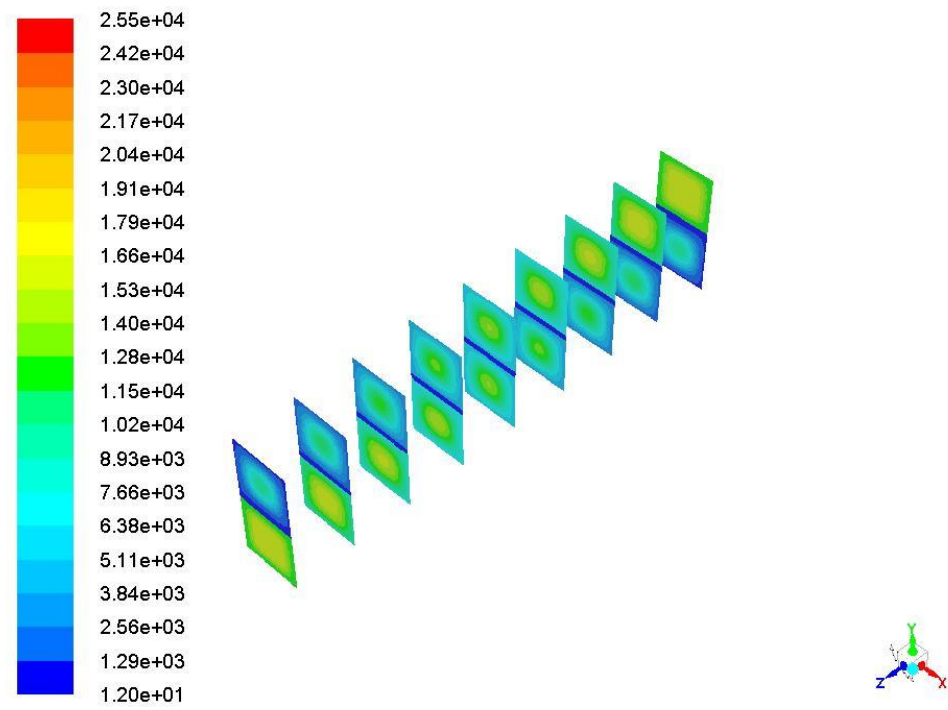

Fig(7) contour show many planes of pressure (pa) along cold and hot cell of $\mathrm{CFMCHX}$ at $\mathrm{D}_{\mathrm{h}}=50 \mu \mathrm{m}$ and $\mathrm{Re}=100$

Fig.8 shows contour of variation temperature distribution a long ( $\mathrm{CFMCHX).} \mathrm{The} \mathrm{hot} \mathrm{fluid} \mathrm{entering} \mathrm{at} \mathrm{T}_{\mathrm{h}}$ $=100 \mathrm{C}$ and cold fluid $T_{C}=50 \mathrm{C}$. As seen in this figure the temperature difference in cold channel increase toward fluid while in hot channel decreased due to heat transfer.
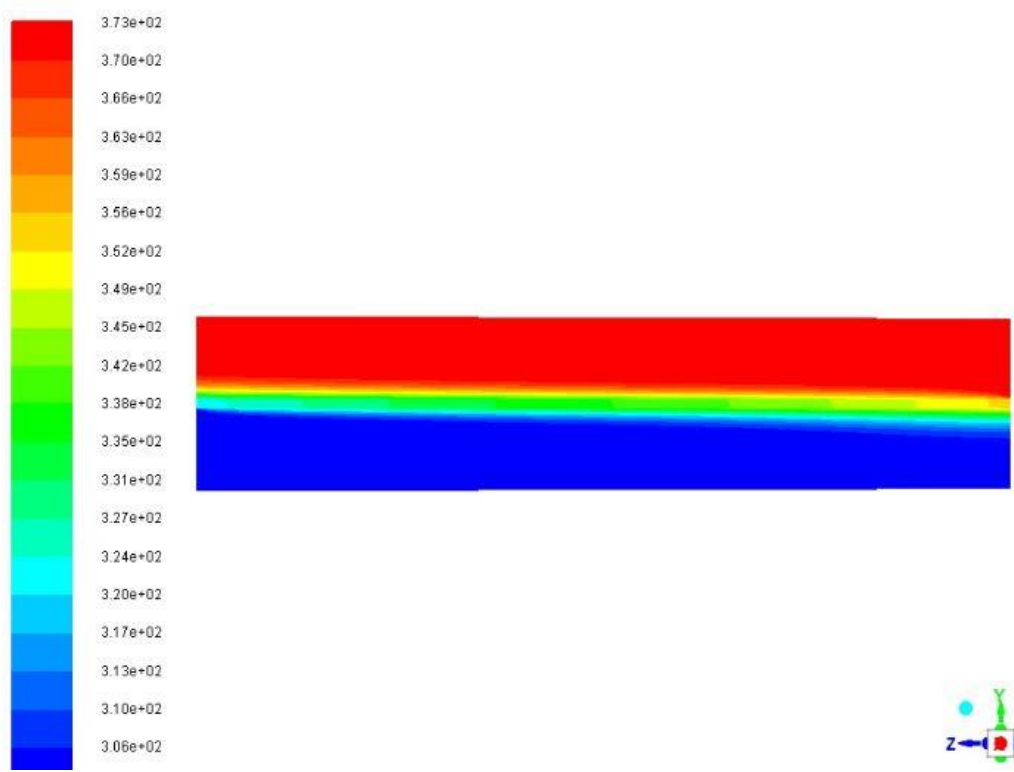

$4+02$

$20 \mathrm{e}+02$

$3177^{6}+02$

$3.06 \mathrm{e} \cdot 02$

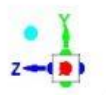

Fig (8) Temperature(k) distribution contour along hot and cold cells of CFMCHX as $R e=100$ and $D_{h}=$ $50 \mu \mathrm{m}$ 


\section{AL-QADISIYAH JOURNAL FOR ENGINEERING SCIENCES}

Vol. 11 , No. 4

ISSN: $1998-4456$

Fig.9 shows the variation of temperature on contours on many planes distributed along the channels of (CFMCHX). As can be seen from this figure that the temperature increased with increase residence time and decreased the velocity of flow.
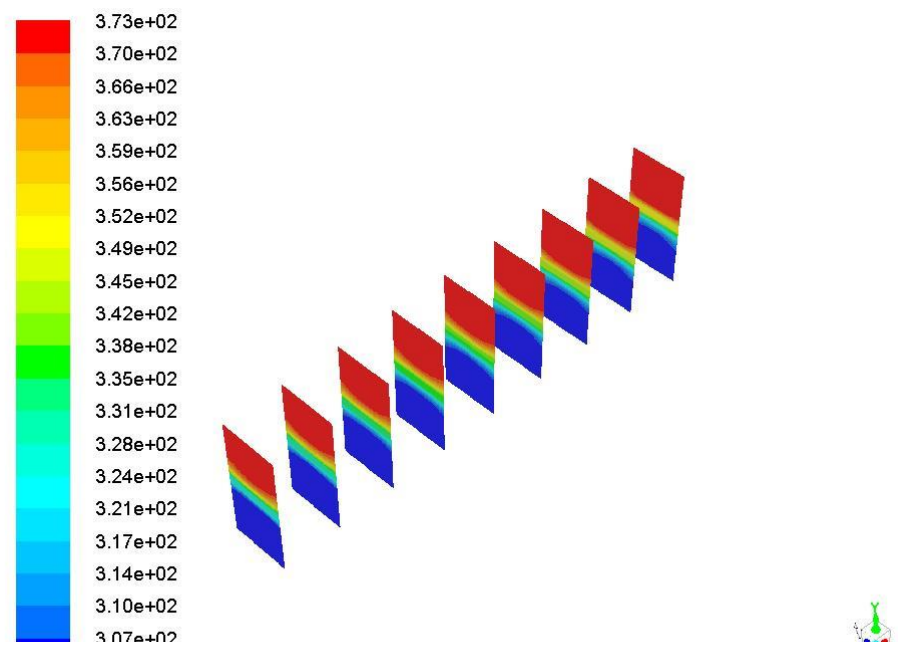

Fig(9) many planes of Temperature(k) explaining as contour at $D_{h}=50 \mu \mathrm{m}$ and $R e=100$

Fig.10 shows the variation of effectiveness with Reynolds number at different values of hydraulic diameter $(20,50,110,150) \mu \mathrm{m}$ with considering roughness effect and neglecting it. It can be seen from this figure that the effectiveness decreased with increasing Reynold number for all diameters due to decreasing temperature difference with increase the velocity of flow. For all selected range of hydraulic diameters it can been noted in fig.10 decreasing the effectiveness with increasing values of hydraulic diameter because the area of heat transfer increasing with size. Also it can be observed that, the effect of surface roughness is small on the effectiveness which is due to independent of temperature on roughness as a result of constant properties assumption.

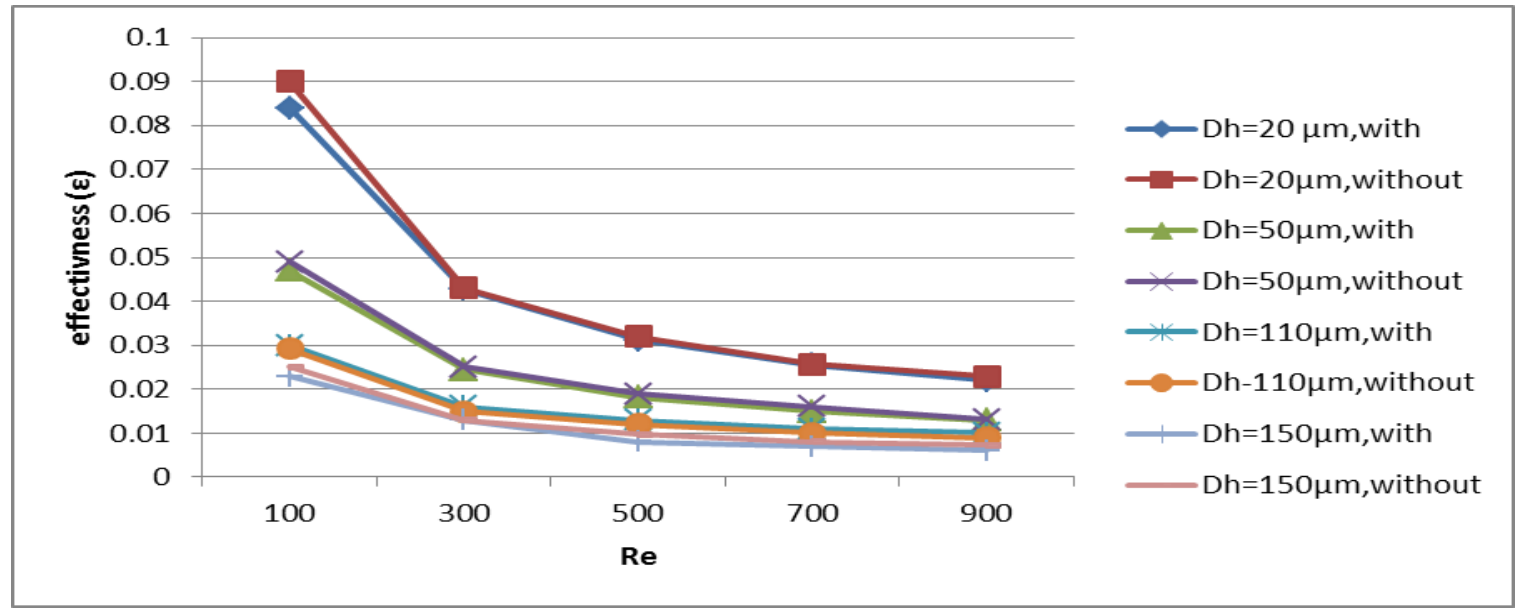

Fig (10) show variation of effectiveness ( $\varepsilon$ ) with Re number with and without considering roughness effect. 


\section{AL-QADISIYAH JOURNAL FOR ENGINEERING SCIENCES}

Vol. 11 , No. 4

ISSN: $1998-4456$

Fig.11 shows the variation of changing in friction factor ( the difference between friction factor with roughness effect and friction factor without it ) with Reynolds number for selected range of hydraulic diameters $(20,50,110,150) \mu \mathrm{m}$. From this figure it can be noted that, The change in friction factor decreased with increasing Reynolds number due to increase the velocity of flow according to Darcy equatio.

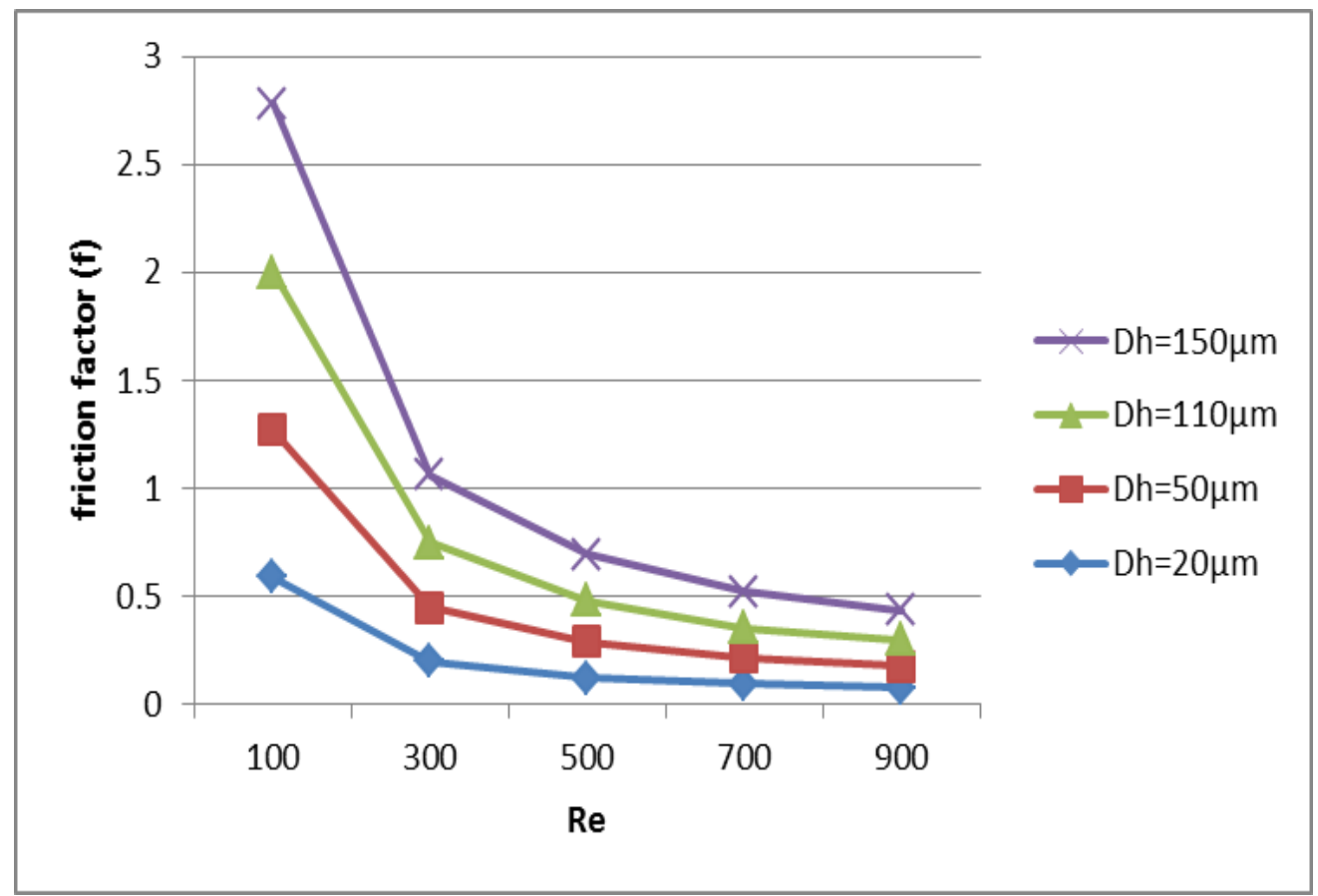

Fig (11) explain variation of friction factor with Re for different values of hydraulic diameter

Fig. 12 explains the relation between pressure drop difference and Reynolds number at different hydraulic diameters. The pressure drop difference in this figure represents the difference between value of pressure drop with considering surface roughness and with neglecting it. As can be observed in the fig.12 The pressure drop difference is maximum at small diameters due to decreasing the area of flow. This figure shows that, pressure drop difference is increased with increasing Reynolds number due to increasing the velocity of flow since the losses is maximized at higher velocity. The surface roughness has very important roll on increasing the value of pressure drop because of the resistance which is show against the fluid flow. 


\section{AL-QADISIYAH JOURNAL FOR ENGINEERING SCIENCES}

Vol. 11 , No. 4

ISSN: $1998-4456$

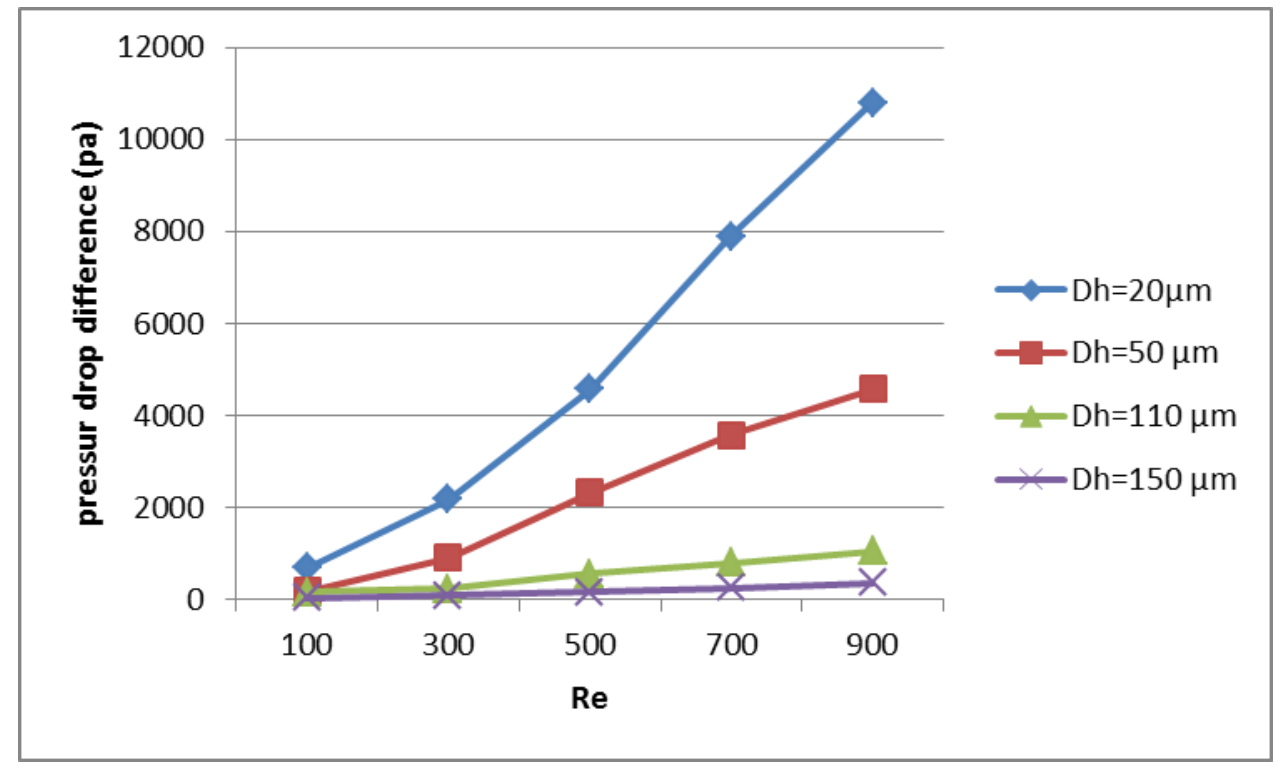

Fig(12) variation pressure drop difference with Re for different value of hydraulic diameter

Fig.13 shows the variation of decrement of pumping power (the altterence between the value of pumping power with roughness effect and its value with neglecting it) with Reynolds number through many values of hydraulic diameter. As can be seen in fig. 13 the difference of pumping power increased with increasing the Reynolds number because of increasing the pressure drop and velocity of flow. Also it can be seen in this figure that, the pumping power is increased with decreasing hydraulic diameter due to high pressure generated in small diameter. The roughness effects work to increase pumping power value and hydraulic performance generally because of the resistance which causes it.

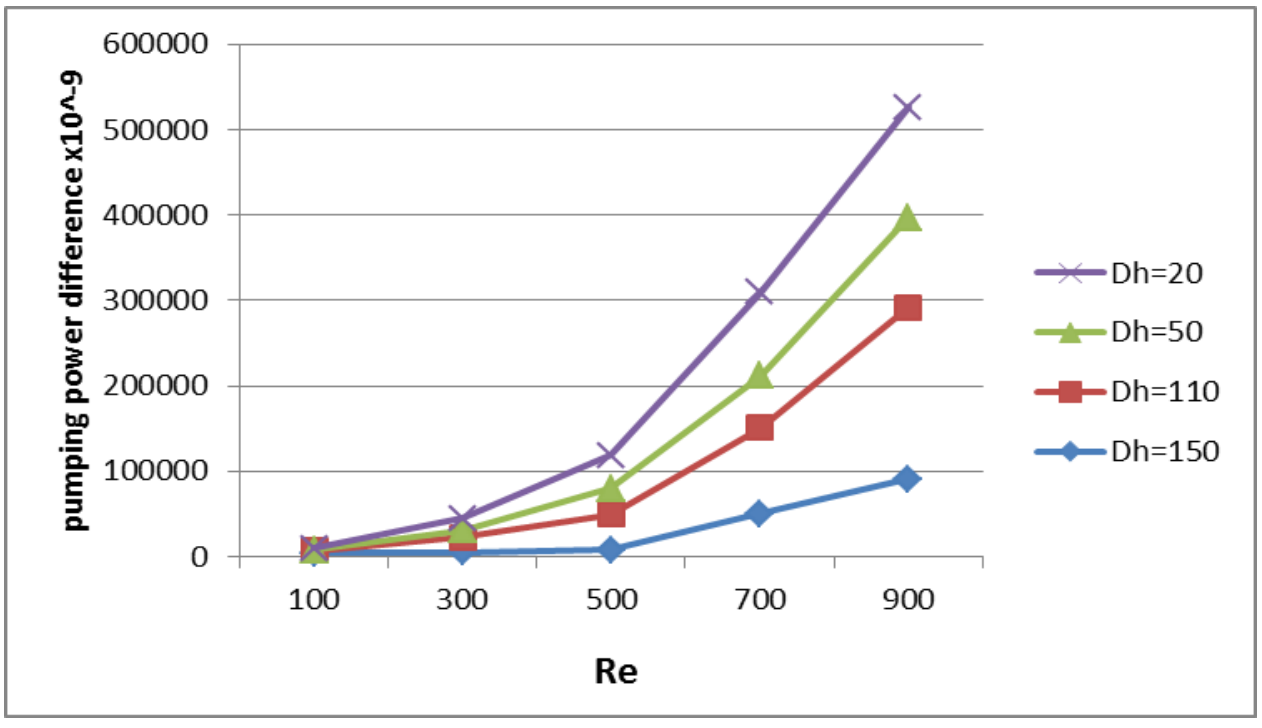

Fig (13) variation of pumping power difference with Re for different hydraulic diameter 


\section{AL-QADISIYAH JOURNAL FOR ENGINEERING SCIENCES}

Vol. 11, No. 4

ISSN: $1998-4456$

Fig.14 represent cooperation between performance factor( it is ratio of heat transfer rate to pumping power) and Reynolds number for two cases, one depending the surface roughness and another neglecting it. The fig (14) divided to (a) and (b) to explain clear variation with different values of hydraulic diameters. The fig (14a) plotted for diameters range (20,50 ) $\mu \mathrm{m}$ while (14 b) plotted for diameter values (110, 150$) \mu \mathrm{m}$. From these figures it can be seen that, the performance factor decreased with increasing Reynolds for all values of hydraulic diameter due to the increasing of pumping power very high comparison with increasing in convective heat transfer. The roughness effect becomes very clear on overall performance with larger hydraulic diameter. Also these figures reveal that, the effect of roughness increased at lower values of Re.

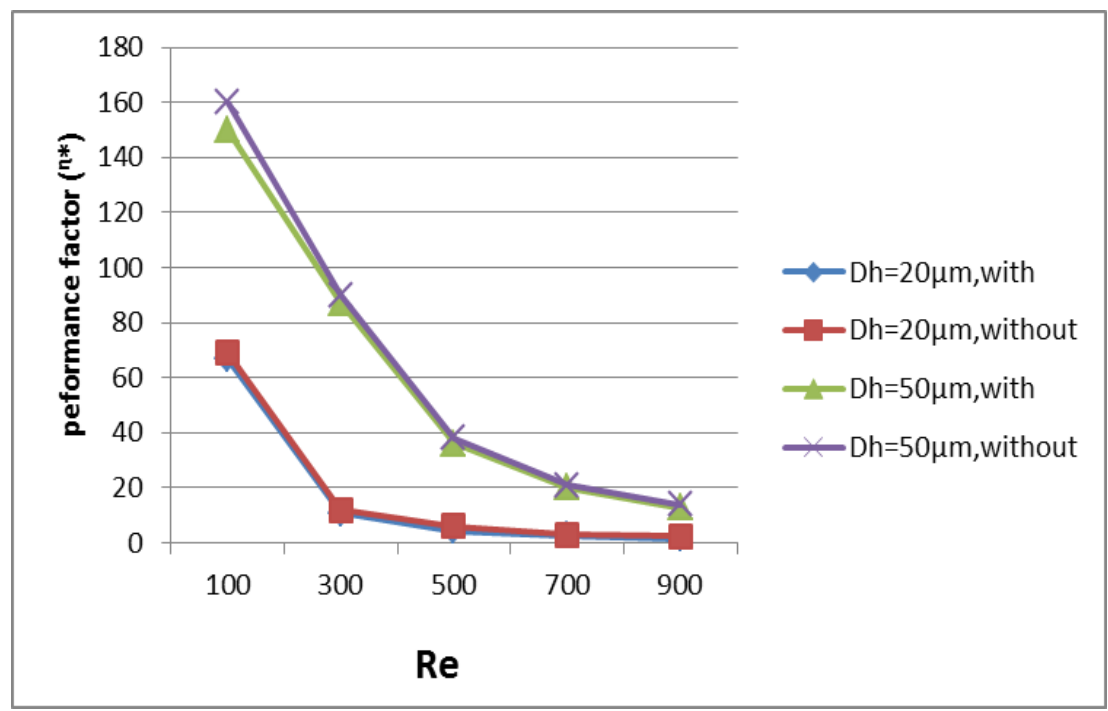

Fig(14-a) variation performance factor with Re for two cases with and without considering roughness effect for hydraulic diameter $(20,50) \mu \mathrm{m}$

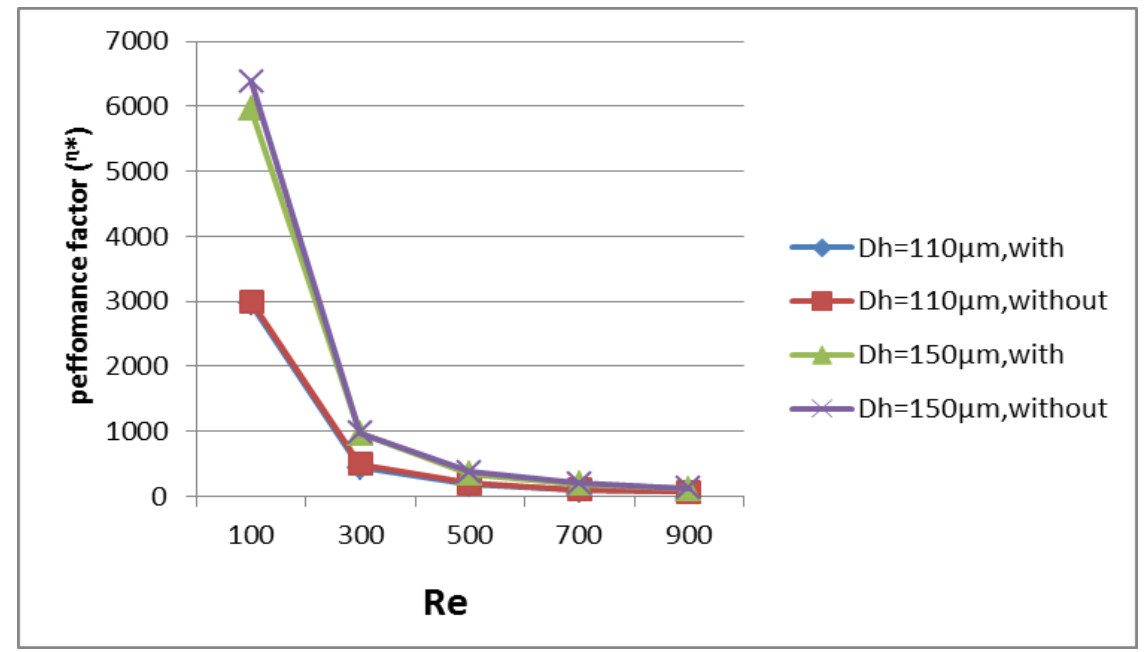

Fig(14-b) variation performance factor with $\mathrm{Re}$ for two cases with and without considerina rouahness effect for hvdraulic diameter(110. 150) um 


\section{CONCLUATIONS}

In this paper numerical investigation is made to study the effect of roughness on the performance of CFMCHX with different sizes and used water at constant properties as working fluid. From the results it can be conclude that:

1- The surface roughness has considerable effect on hydraulic performance and its effect is increased when hydraulic diameter and velocity of flow is small.

2- Surface roughness enhances the thermal performance slightly.

3- The roughness effect is decreased with increasing Reynold number and hydraulic diameter.

4- The surface roughness causes an extra increasing in pressure drop and pumping power.

5- In general the surface roughness leads to decrease the overall performance of CFMCHX.

\section{REFERENCES}

1. Hasan, M. I. (2011). Influence Of Wall Axial Heat Conduction On The Forced Convection Heat Transfer In Rectangular Channels. Basrah Journal for Engineering Science, 1, 31-43.

2. Mala, G. M., \& Li, D. (1999). Flow characteristics of water in microtubes. International journal of heat and fluid flow, 20(2), 142-148.

3. Weilin, Q., Mala, G. M., \& Dongqing, L. (2000). Pressure-driven water flows in trapezoidal silicon microchannels. International journal of heat and mass transfer, 43(3), 353-364.

4. Qu, W., Mala, G. M., \& Li, D. (2000). Heat transfer for water flow in trapezoidal silicon microchannels. International Journal of Heat and Mass Transfer, 43(21), 3925-3936.

5. Hasan, M. I., Rageb, A. A., Yaghoubi, M., \& Homayoni, H. (2009). Influence of channel geometry on the performance of a counter flow microchannel heat exchanger. International Journal of Thermal Sciences, 48(8), 1607-1618.

6. Dang, T., Teng, J. T., \& Chu, J. C. (2010). A study on the simulation and experiment of a microchannel counter-flow heat exchanger. Applied Thermal Engineering, 30(14-15), 2163-2172.

7. Kim, B. (2016). An experimental study on fully developed laminar flow and heat transfer in rectangular microchannels. International Journal of Heat and Fluid Flow, 62, 224-232.

8. Hasan, M. I. (2011). Numerical investigation of counter flow microchannel heat exchanger with MEPCM suspension. Applied Thermal Engineering, 31(6-7), 1068-1075.

9. Peiyi, W., \& Little, W. A. (1983). Measurement of friction factors for the flow of gases in very fine channels used for microminiature Joule-Thomson refrigerators. Cryogenics, 23(5), 273-277.

Page $444 \quad$ Copyright $\odot 2018$ Al-Qadisiyah Journal For Engineering Sciences. All rights reserved. 
10. Hassan, M. I. Numerical investigation of counter flow microchannel heat exchanger with different geometries working fluid, PhD thesis, Mechanical engineering department, college of engineers, Basrah university.

11. Qi, S. L., Zhang, P., Wang, R. Z., \& Xu, L. X. (2007). Single-phase pressure drop and heat transfer characteristics of turbulent liquid nitrogen flow in micro-tubes. International journal of heat and mass transfer, 50(9-10), 1993-2001.

12. Hasan, M. I., Rageb, A. M. A., \& Yaghoubi, M. (2012). Investigation of a counter flow microchannel heat exchanger performance with using nanofluid as a coolant. Journal of Electronics Cooling and Thermal Control, 2(2), 35-43.

13. Shakir, A. M., Mohammed, A. K., \& Hasan, M. I. (2011). Numerical investigation of counter flow microchannel heat exchanger with slip flow heat transfer. International Journal of Thermal Sciences, 50(11), 2132-2140.

14. Al-Bakhit, H., \& Fakheri, A. (2006). Numerical simulation of heat transfer in simultaneously developing flows in parallel rectangular ducts. Applied thermal engineering, 26(5-6), 596-603. 